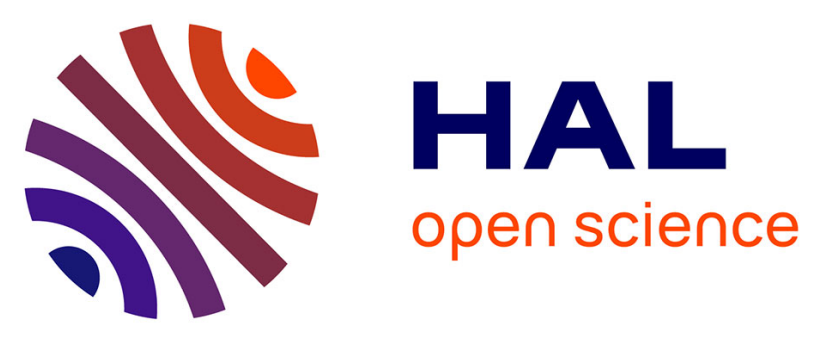

\title{
Pharmacometabolomics of docetaxel-treated human MCF7 breast cancer cells provides evidence of varying cellular responses at high and low doses
}

\author{
Mathilde Bayet-Robert, Daniel Morvan, Philippe Chollet, Chantal
} Barthomeuf

\section{To cite this version:}

Mathilde Bayet-Robert, Daniel Morvan, Philippe Chollet, Chantal Barthomeuf. Pharmacometabolomics of docetaxel-treated human MCF7 breast cancer cells provides evidence of varying cellular responses at high and low doses. Breast Cancer Research and Treatment, 2009, 120 (3), pp.613-626. 10.1007/s10549-009-0430-1 . hal-00535372

\section{HAL Id: hal-00535372 \\ https://hal.science/hal-00535372}

Submitted on 11 Nov 2010

HAL is a multi-disciplinary open access archive for the deposit and dissemination of scientific research documents, whether they are published or not. The documents may come from teaching and research institutions in France or abroad, or from public or private research centers.
L'archive ouverte pluridisciplinaire $\mathbf{H A L}$, est destinée au dépôt et à la diffusion de documents scientifiques de niveau recherche, publiés ou non, émanant des établissements d'enseignement et de recherche français ou étrangers, des laboratoires publics ou privés. 


\title{
Pharmacometabolomics of docetaxel-treated human MCF7 breast cancer cells provides evidence of varying cellular responses at high and low doses
}

\author{
Mathilde Bayet-Robert · Daniel Morvan • \\ Philippe Chollet - Chantal Barthomeuf
}

Received: 19 January 2009/Accepted: 23 May 2009/Published online: 10 June 2009

(C) Springer Science+Business Media, LLC. 2009

\begin{abstract}
There is growing evidence that docetaxel, a microtubule-targeting agent like the other taxane paclitaxel, induces dual cytotoxicity mechanism according to dose level. Postgenomics screening technologies are now more and more applied to the elucidation of drug response mechanisms. Proton nuclear magnetic resonance spectroscopy-based pharmacometabolomics was here applied to get further insight into the response of human MCF7 breast carcinoma cells to docetaxel at high (clinical, $5 \mu \mathrm{M}$ ) and low $(1 \mathrm{nM})$ doses. The global response to both doses was evaluated by nuclear morphology and DNA content, the latter as an index of cell proliferation and DNA ploidy. High dose provoked long-lasting cell cycle arrest in mitosis during the first $48 \mathrm{~h}$ of exposure to treatment and severe decrease in DNA content followed by significant amount of cell death. In contrast, at low dose, no long-lasting cell cycle arrest was observed on micrographies, and DNA content was decreased but less than at high dose $(P<0.05)$, without significant cell death. This response was compared to biochemical alteration assessed by pharmacometabolomics. Thirty metabolites were identified and quantified. Metabolite profiling at clinical dose revealed time-dependent disorders in derivatives of glycolysis, lipid metabolism and glutathione metabolism.
\end{abstract}

The authors Mathilde Bayet-Robert and Daniel Morvan equally contributed to this work.

M. Bayet-Robert · D. Morvan ( $\square)$ · P. Chollet Centre Jean Perrin, Université d'Auvergne, 58 Rue

Montalembert, 63011 Clermont-Ferrand, France

e-mail: Daniel.MORVAN@u-clermont1.fr

C. Barthomeuf

Faculté de Pharmacie, 28 Place Henri Dunant, 63001 Clermont-

Ferrand, France
Comparison between high and low doses was performed at $72 \mathrm{~h}$ and showed common traits including the accumulation of cytidinediphosphocholine $(\times 5.0$ and $\times 6.9$, respectively, $P<0.03)$, the decrease in phosphatidylcholine $(\times 0.3$ and $\times 0.2$, respectively, $P<0.03)$, and gluthathione $(\times 0.6$ and $\times 0.6$, respectively, $P<0.03)$. Despite that, significant dosedependent differences were found in 12 of 30 measured metabolites. Among them, the most discriminant metabolites were polyunsaturated fatty acids (ratio of high-to-low dose of 14.8, $P<0.05$ ), glutamate, myoinositol, and homocysteine (ratio $<0.4, P<0.05$ ). In addition, the mechanism for glutathione decrease was different. At high dose, it resulted from extensive consumption with precursor starvation (glutamate: $-89 \%, P<0.05$ ) and increased glutathione $S$-transferase activity $(\times 5, P<0.01)$, whereas at low dose, it resulted from glutathione biosynthesis blockade with homocysteine accumulation $(+144 \%, P<0.03)$ and decreased glutathione $S$-transferase activity $(-70 \%$, $P<0.01$ ). Altogether, this pharmacometabolomics analysis provides further evidence of the varying cellular responses at high and low doses of docetaxel in MCF7 breast cancer cells.

Keywords MCF7 breast cancer cells - Docetaxel . Dose dependence $\cdot$ Cytotoxicity $\cdot$ Adaptive response Pharmacometabolomics - Metabolite kinetics . Phospholipid metabolism - Glutathione metabolism
Abbreviations
DTX Docetaxel
HRMAS High resolution magic angle spinning
${ }^{1} \mathrm{H}-\mathrm{NMR}$ Proton nuclear magnetic resonance
CBS Cystathionine beta-synthase
CPT Choline phosphotransferase
DAG Diacylglycerol 
PA Phosphatidic acid

PKC Protein kinase C

\section{Introduction}

Breast cancer is one of the most frequent invasive cancers in women in industrialized countries [1] and is the second leading cause of cancer death [2]. Among novel drugs for the treatment of advanced or metastatic breast cancer, microtubule-targeting agents as taxanes appear the most effective for survival prolongation. Taxanes include two members, paclitaxel and docetaxel (DTX). DTX is used as the neoadjuvant or adjuvant standard treatment in association with anthracyclines [3] and also as a monotherapy in anthracycline-refractory metastatic breast cancer patients $[4,5]$. DTX was shown to interrupt the normal mitotic process through the disruption of microtubules [6], to have antiangiogenic effect [7], to activate several apoptotic cellular signals such as protein kinases and caspases [8,9], and to decrease structural and antioxidative gene expression $[10,11]$. Reactive oxygen and nitrogen species have been reported to be involved in taxane cytotoxicity [12, 13], resulting from activation of NADPH oxidase [14]. Also DTX increased inducible nitric oxide synthase (iNOS) expression [15] and subsequent nitric oxide (NO) production [16] in breast cancer cells and through the stimulation of p38 activity in alveolar macrophages [17]. At low concentration (10 nM), DTX was shown to activate diacylglycerol (DAG) kinase, a lipid kinase that phosphorylates DAG into phosphatidic acid (PA) [18]. Recently, the dose dependence of the response of human breast carcinoma cells to DTX has been reported [10]. Like paclitaxel [19], DTX provoked striking differences in cell cycle according to the dose. At low dose (2-4 nM), DTX induced aberrant mitosis followed by aneuploidy, whereas at clinical concentration $(100 \mathrm{nM})$ it induced sustained mitotic arrest followed by mitotic slippage [20, 21]. Postgenomics screening technologies like transcriptomics, proteomics, and metabolomics are now more and more applied to the elucidation of drug response mechanisms and the identification of biomarkers of the response. In this work, we used nuclear magnetic resonance (NMR) spectroscopy-based metabolomics [22] to get further insight into the response of MCF7 tumor cells to high (clinical, $5 \mu \mathrm{M}$ ) and low $(1 \mathrm{nM})$ doses of DTX. The global response of MCF7 cells to DTX was investigated by nuclear morphology and DNA content measurement, the latter as an index of cell proliferation and DNA ploidy. At high dose, nuclear morphology showed a long-lasting cell cycle arrest in mitosis during the first $48 \mathrm{~h}$ of exposure to DTX, severe decrease in DNA content of attached cells, followed with reduction in DNA content testifying cell death. In contrast, at low dose, no long-lasting cell cycle arrest was observed, and the DNA content was decreased, but less than at high dose without significant cell death. The global response was compared to biochemical disorders using pharmacometabolomics. Among the 30 identified and quantified metabolites, polyunsaturated fatty acid, glutamate, myoinositol, and homocysteine showed the largest variations and discriminated the responses to high and low doses. At both doses, a common response of phosphatidylcholine biosynthesis blockade and glutathione decrease was found. However, the mechanism for glutathione decrease was obviously different. At high dose, the decrease in GSx levels was related to extensive consumption and precursor starvation, whereas at low dose, it was related to blockade of transsulfuration. Altogether, our pharmacometabolomics investigation provides further insight into the mechanism of the varying cellular responses of MCF7 breast cancer cells to high and low doses of DTX and also offers a basis for translational studies of metabolites altered in response to DTX into clinical endpoints.

\section{Materials and methods}

\section{Chemicals}

Docetaxel was purchased from Sigma-Aldrich (Saint Quentin Fallavier, France) and was prepared as $1 \mathrm{nM}$ or $5 \mu \mathrm{M}$ solution in $0.5 \%$ DMSO. $\mathrm{D}_{2} \mathrm{O}$ (SDS, Peypin, France) was used as a solvent and a locking medium for NMR spectroscopy.

\section{Cell culture}

MCF7 human breast carcinoma cells were purchased from the European Collection of Cell Cultures (Salisbury, UK). Cells were cultured at $37^{\circ} \mathrm{C}$ in humidified atmosphere containing 5\% $\mathrm{CO}_{2}$, using an Eagle's MEM-GlutaMAX medium (Life Technologies, USA) supplemented with $10 \%$ of heat-inactivated fetal calf serum, $1 \%(\mathrm{v} / \mathrm{v})$ of a $200 \mathrm{mM} \mathrm{L}$-glutamine solution, and $1 \%(\mathrm{v} / \mathrm{v})$ of a $100 \mathrm{nM}$ sodium pyruvate solution and maintained in exponential growth. MCF7 cells were plated in triplicate into 96-well plates at a density of $3.5 \times 10^{4}$ cells/well for DNA content measurement, T75 flasks $\left(1 \times 10^{6}\right.$ cells/flask $)$ for GST activity assay and microscopy analysis, or T180 flasks $\left(10 \times 10^{6}\right.$ cells/flask $)$ for NMR spectroscopic analysis.

\section{Cell treatment}

Two doses of DTX were chosen. The low dose $(\ell, 1 \mathrm{nM})$ corresponded to the $\mathrm{IC}_{50}$ of MCF7 cells after $48 \mathrm{~h}$ exposure 
to DTX. The clinical dose (high dose, $H, 5 \mu \mathrm{M}$ ) was determined by extrapolation of clinical data as follows: in patient, after $1 \mathrm{~h}$ perfusion of $100 \mathrm{mg} \mathrm{m}^{-2}$ DTX (monotherapy standard dose in advanced or metastatic breast cancer), the mean of the maximal plasmatic concentration reaches $3.7 \mathrm{mg} \mathrm{ml}^{-1}$, namely $4.6 \mathrm{mM}$. To be extrapolated to MCF7 cell culture treatment, the equivalent clinical dose of DTX was calculated as: [plasma concentration $(4.6 \mathrm{mM})$ $\times$ cell culture medium volume $(30 \mathrm{ml})] /$ clinical volume of distribution $(\sim 301) \simeq 5 \mu \mathrm{M}$.

Cells were exposed to $5 \mu \mathrm{M}$ DTX, $1 \mathrm{nM}$ DTX, or the vehicle $(0.5 \%$ DMSO) for $6,12,16,24,36,48,72$, and 96 h. After each treatment and before analysis, cells were washed twice with PBS (100 $\mu$ l per well or 10-20 ml per flask) to remove detached and dead cells. The $\mathrm{pH}$ of each medium was measured.

\section{DNA content measurement}

DNA content of MCF7 cells was measured after cell lysis, using Hoescht 33342 staining [23]. DNA content was an index of biomass and ploidy of attached cells. Briefly, $100 \mu \mathrm{l}$ of a $0.01 \%(\mathrm{~m} / \mathrm{v})$ SDS solution in sterile distilled water was distributed into each well. Cells were then incubated for $1 \mathrm{~h}$ at room temperature and frozen at $-80^{\circ} \mathrm{C}$ for $1 \mathrm{~h}$. After thawing (approximately $15 \mathrm{~min}$ ), $100 \mu \mathrm{l}$ of Hoechst 33342 solution at $30 \mu \mathrm{g} \mathrm{ml}^{-1}$ in a hypersaline buffer (10 mM Tris$\mathrm{HCl}, \mathrm{pH} 7.4,1 \mathrm{mM}$ EDTA, and $2 \mathrm{M} \mathrm{NaCl}$ ) was added to each well. Plates were incubated in this solution for $1 \mathrm{~h}$ and protected from light at room temperature on a plate shaker. Fluorescence was then measured on a microplate fluorometer (Fluoroskan Ascent FL, Thermolabsystem, Helsinki, Finland) using an excitation wavelength of $360 \mathrm{~nm}$ and an emission wavelength of $460 \mathrm{~nm}$.

MCF7 cell death at $72 \mathrm{~h}$ was estimated from DNA content measurement as: [(mean of treated cells at $36 \mathrm{~h})-($ mean of treated cells at $72 \mathrm{~h})] /($ mean of treated cells at $36 \mathrm{~h}) \times 100$.

Optical and fluorescence microscopy analysis

Membrane integrity of MCF7 cells was assessed using the Trypan Blue exclusion test. Membrane permeation to the dye reflected the imbalance of membrane phospholipid composition. A membrane integrity index was defined as: [(count of intact membrane cells) - (count of injured membrane cells) $] /($ count of injured membrane cells $) \times 100$, in a minimum of 100 cells.

For quantification of abnormal nuclear morphology, cells were collected, fixed with absolute ethanol and acetic acid (3/1) (v/v), and spread on microscope slides. DNA was labeled with Hoechst 33342. An average of 600 cells was randomly counted in several areas of the slide, and nuclear morphology was assessed under fluorescence microscopy (magnification $60 \times$ ).

\section{Total GST activity assay}

Total (cytosolic and microsomal) glutathione $S$-transferase (GST) activity was assayed by conjugation of 1-chloro-2,4dinitrobenzene (CDNB) with reduced glutathione (GSH), using the Glutathione $S$-Transferase Assay Kit (Cayman Chemical Company, Ann Arbor, MI, USA). MCF7 cells were harvested using a rubber policeman and centrifugated at $1,500 \times g$ for $10 \mathrm{~min}$ at $4^{\circ} \mathrm{C}$. Cell pellets were resuspended in $1 \mathrm{ml}$ of cold buffer $(100 \mathrm{mM}$ potassium phosphate, $\mathrm{pH} 7.0$, containing $2 \mathrm{mM}$ EDTA). Cell suspensions were then sonicated for $30 \mathrm{~s}$ on ice and centrifugated at $10,000 \times g$ for $15 \mathrm{~min}$ at $4^{\circ} \mathrm{C}$. Supernatant was used for GST measurement according to a modified version of that described in cell homogenates by Habig et al. [24]. Briefly, $10 \mu \mathrm{l}$ of CDNB, $20 \mu \mathrm{l}$ of GSH, and $150 \mu \mathrm{l}$ of assay buffer (100 $\mathrm{mM}$ potassium phosphate, $\mathrm{pH} 6.5$, containing $0.1 \%$ Triton X-100) were added to $20 \mu$ l of sample. Nonenzymatic sample contained $170 \mu \mathrm{l}$ of assay buffer and $20 \mu \mathrm{l}$ of $\mathrm{GSH}$. The formation of the $S$-conjugate induced an increase in absorbance at $340 \mathrm{~nm}$ monitored every $60 \mathrm{~s}$ for $6 \mathrm{~min}$, using a DU800 spectrophotometer (Beckman Coulter, Villepinte, France) at $25^{\circ} \mathrm{C}$.

\section{NMR spectroscopy-based metabolomics}

MCF7 cells were collected by centrifugation $(1,500 \times g$ for $10 \mathrm{~min}$ at $\left.4^{\circ} \mathrm{C}\right)$. Cell pellets were washed twice with $1 \mathrm{ml} \mathrm{D}_{2} \mathrm{O}-\mathrm{PBS}\left(10 \mathrm{~g}^{-1}\right)$ and frozen at $-80^{\circ} \mathrm{C}$, in prevision of pharmacometabolomics analysis. Five to $10 \times 10^{6}$ intact cells were used for each NMR spectroscopy acquisition. High resolution magic angle spinning (HRMAS) proton $\left({ }^{1} \mathrm{H}\right)-\mathrm{NMR}$ spectroscopy was performed at $500 \mathrm{MHz}$ (Bruker DRX-500, Karlsruhe, Germany). Intact MCF7 cell pellets with $5 \mu \mathrm{D}_{2} \mathrm{O}-\mathrm{PBS}$ were set into 4-mm-diameter, 50- $\mu$ z zirconia rotor tubes without upper spacer. Rotors were spun at $4 \mathrm{kHz}$ at room temperature. NMR spectroscopy acquisition and processing were run from a workstation (Silicon Graphics, Inc., USA).

The acquisition technique involved both one-dimensional (1D) ${ }^{1} \mathrm{H}-\mathrm{NMR}$ spectra and two-dimensional (2D) ${ }^{1} \mathrm{H}-\mathrm{NMR}$ spectra. The $1 \mathrm{D}$ sequence was a saturationrecovery sequence with an $8 \mu$ s radiofrequency pulse, water signal suppression at low power, a $10 \mathrm{ppm}$ spectral width, $8 \mathrm{~K}$ complex data points, a $10 \mathrm{~s}$ relaxation delay, and 32 repetitions. After Fourier transformation, a baseline correction was applied using a spline algorithm in the spectral domain of interest. Peak referencing was done on 
the signal of 3-trimethylsilyl-propane sulfonate. Metabolites that did not give rise to correlation signals in $2 \mathrm{D}$ spectra, namely those identified from their methyl group [total creatine $(\mathrm{tCr}=$ creatine + phosphocreatine $)$ at $3.03 \mathrm{ppm}$, acetate (Ace) at $1.92 \mathrm{ppm}$, and phosphatidylcholine (PtC) at $3.26 \mathrm{ppm}$ [25], or from their uncoupled methylene signal (glycine (Gly) at $3.56 \mathrm{ppm}$ ) were measured in the 1D spectrum, using deconvolution procedures (XWIN-NMR v2.6 software, Bruker).

The 1D NMR spectrum was immediately followed by a $2 \mathrm{D}$ NMR spectrum. The used sequence was a $2 \mathrm{D}$ total correlation spectroscopy (TOCSY) sequence. It was performed with water signal suppression at low power, with a $6 \mathrm{ppm}$ spectral bandwidth along both frequency axes (256 samples along the first axis and $2 \mathrm{~K}$ samples along the second axis), a mixing time of $75 \mathrm{~ms}$ during which the spin-lock pulse train (DIPSI-2) was applied, a 1-s relaxation delay, and 16 repetitions. The 2D NMR spectrum lasted 1:41 h duration in excellent compatibility with the preservation of the sample in the magnet at room temperature. For quantification, a new procedure for NMR-based metabolite profiling was applied [22]. Quantified metabolites in 2D NMR spectra were polyunsaturated fatty acid (PUF) at $2.79-5.33 \mathrm{ppm}$, lactate (Lac) at $1.34-4.11 \mathrm{ppm}$, alanine (Ala) at $1.47-3.77 \mathrm{ppm}$, glutamine (Gln) at 2.12-2.46 ppm, glutamate (Glu) at 2.06-3.76 ppm, aspartate (Asp) at 2.70/2.80-3.89 ppm, hypotaurine (hTa) at 2.63-3.35 ppm, taurine (Tau) at 3.27$3.43 \mathrm{ppm}$, total glutathione $(\mathrm{GSx}=$ [reduced glutathione, $\mathrm{GSH}$ ] $+2 \times$ [oxidized glutathione, GSSG]; [25]) at 2.17$2.55 \mathrm{ppm}$, arginine (Arg) at 1.68/1.92-3.23 ppm, lysine (Lys) at 1.90-3.77 ppm, threonine (Thr) at 1.32-3.58 ppm, choline (Cho) at 3.55-4.07 ppm, phosphocholine (PC) at 3.62-4.18 ppm, glycerophosphocholine (GPC) at 3.66$4.34 \mathrm{ppm}$, phosphoethanolamine (PE) at 3.22-3.99 ppm, glycerophosphoethanolamine (GPE) at $3.30-4.12 \mathrm{ppm}$, $N$-acetylaspartate (NAA) at 2.50/2.70-4.40 ppm, myoinositol (MyI) at 3.54/3.61-3.48 ppm, proline (Pro) at 2.034.15 ppm, asparagine (Asn) at 2.88/2.95-3.99 ppm, homocysteine (Hcy) at 2.17-2.72 ppm, methionine (Met) at 2.14/ 2.20-2.63 ppm, phenylalanine (Phe) at 3.13-3.99 ppm, cytidinediphosphocholine (CDPC) at 3.66-4.42 ppm, and polyamines (Ply) at $1.80-3.10 \mathrm{ppm}$. The percentage variation of each quantified metabolite in treated cells was calculated as: [(mean of treated cells) - (mean of control cells $)] /($ mean of control cells $) \times 100$.

\section{Statistical methods}

Three to five independent experiments were performed for each time point. Statistical comparisons between groups were performed using the nonparametric Mann-Whitney test. Differences were considered statistically significant for $P<0.05$.

\section{Results}

Global response of MCF7 cells to docetaxel

DNA content (\% of control) of MCF7 cells exposed to DTX for $72 \mathrm{~h}$ decreased with increasing drug concentrations (Fig. 1a). DTX-treated MCF7 cells were morphologically assessed (Fig. 1b, c). Mitotic arrest was of $6.3 \%$ at $24 \mathrm{~h}$ $(P<0.05), 2.2 \%$ at $48 \mathrm{~h}(P=\mathrm{NS})$, and $0.7 \%$ at $72 \mathrm{~h}$ $(P=$ NS) at low dose of DTX (Fig. 1b). At high dose, a peak of mitotic arrest was observed in MCF7 cells of $34.7 \%$ at $24 \mathrm{~h}(P<0.05), 13.3 \%$ at $48 \mathrm{~h}(P<0.05)$, and $0.7 \%$ at $72 \mathrm{~h}$ (Fig. 1c). No significant apoptosis was found after MCF7 cell exposure to high and low doses of DTX (Fig. 1b, c).

Also extracellular $\mathrm{pH}$ was measured at $72 \mathrm{~h}$. In DTXtreated cell culture medium, $\mathrm{pH}$ was $7.48 \pm 0.13$ versus $7.64 \pm 0.09$ (treated vs. control, $P=0.06$ ) at low dose and $7.44 \pm 0.05$ versus $7.64 \pm 0.09(P<0.01)$ at high dose. Membrane integrity, defined as the percentage of viable cells with intact membrane, was 91,81 , and $65 \%$, respectively, after 12,36 , and $72 \mathrm{~h}$ exposure to high dose of DTX (all, $P=\mathrm{NS}$ ).

At low dose, DNA content increased moderately between 36 and $72 \mathrm{~h}$, from 5.17 to 5.76 in arbitrary units (a.u.), corresponding to 58 and $20 \%$ of control cell DNA content at $36 \mathrm{~h}$ and $72 \mathrm{~h}$, respectively (treated vs. control, $P<0.05$; Fig. 1d). However, at high dose, DNA content was 2.76 a.u. at $36 \mathrm{~h}$ and 2.43 a.u. at $72 \mathrm{~h}$, corresponding to 30 and $8 \%$ of control cell DNA content at 36 and $72 \mathrm{~h}$, respectively $(P<0.05$; Fig. 1e). DNA content was statistically different between low and high doses of $\operatorname{DTX}(P<0.05$, at 12,36 , and $72 \mathrm{~h})$. In attached cells, the amount of dead cells was estimated from DNA content measurement at $72 \mathrm{~h}$ to be $0.3 \%$ (treated vs. control, $P=\mathrm{NS}$ ) at low dose and $12.8 \%$ $(P<0.05)$ at high dose of DTX (low vs. high, $P<0.05$; Fig. 1b, c).

Typical 2D NMR spectra at $72 \mathrm{~h}$ are shown in Fig. 2. In comparison to control, a decrease in the GSx signal and an increase in the CDPC signal were found at high (Fig. 2a, b) and low (Fig. 2a, c) doses of DTX. In contrast, the PUF signal was dramatically increased in the high-dose DTX spectrum only. Detached cells were collected after exposure to high dose of DTX at $72 \mathrm{~h}$ for NMR spectroscopic analysis. NMR spectra of these cells especially showed a high level of PUF (Fig. 2d). In the following metabolomics analysis, 30 metabolites were quantified from NMR spectra of attached cells. 


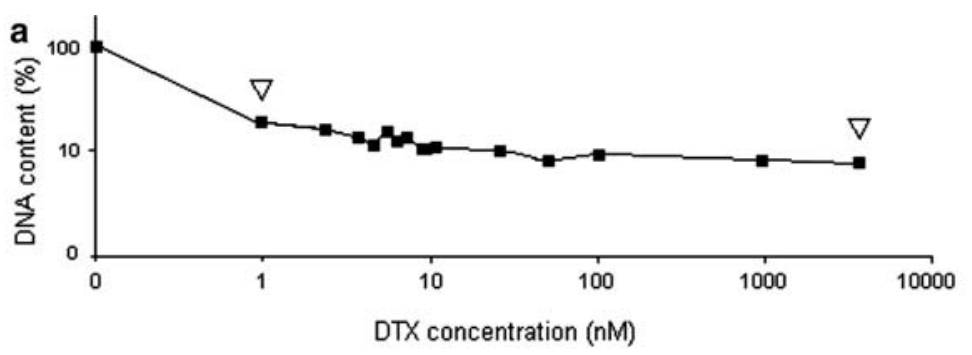

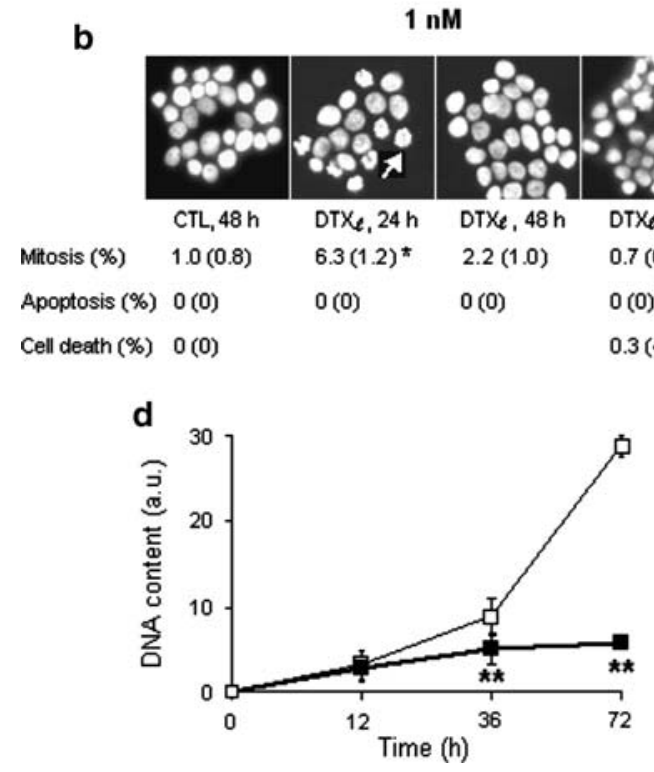

Fig. 1 Global response of attached MCF7 cells to docetaxel (DTX). Before DNA labeling with Hoechst 33342, cells were washed to remove detached cells. Cellular DNA content ( $\%$ of control), an index of cell proliferation and DNA ploidy, was evaluated using the Hoechst fluorescence intensity (in arbitrary units, a.u.). DNA content of attached MCF7 cells was measured in response to increasing concentrations of DTX at $72 \mathrm{~h} \mathrm{(a).} \mathrm{Open} \mathrm{arrows} \mathrm{indicate} \mathrm{doses} \mathrm{of}$ interest (low dose, $1 \mathrm{nM}$ and high dose, $5 \mu \mathrm{M}$ ). DNA content in MCF7 cells treated with $1 \mathrm{nM}$ and $5 \mu \mathrm{M}$ was significantly different from that in control cells, at $72 \mathrm{~h}(P<0.05)$. Dose-dependent global response of attached MCF7 cells to low (left panel) and high (right panel) doses of DTX. Cells were incubated without drug for $48 \mathrm{~h}$ (CTL, control) and with $1 \mathrm{nM}$ DTX ( $\ell$, low dose) for 24,48 , and $72 \mathrm{~h}$ (b), and without drug for $48 \mathrm{~h}(C T L)$, and with $5 \mu \mathrm{M}$ DTX $(H$, high

Metabolomics of MCF7 cell response to docetaxel at clinical dose

Metabolite kinetics $(6,16,24,48,72$, and $96 \mathrm{~h})$ in response to clinical dose of DTX $(5 \mu \mathrm{M})$ is shown in Fig. 3. A biphasic time-response could be described, involving an early phase before $48 \mathrm{~h}$ and a delayed phase after $48 \mathrm{~h}$, matching the phases of the global morphological response. During the early phase $(12-36 \mathrm{~h})$, there were variations of Ala $(-52 \%$ at $6 \mathrm{~h})$, Ace $(-91 \%$ at $6 \mathrm{~h}), \mathrm{tCr}(+75 \%$ at $16 \mathrm{~h})$, Gly (+487\% at $24 \mathrm{~h})$, and Ply $(-45 \%$ at $24 \mathrm{~h}$; all, $P<0.05)$. During the delayed phase, significant variations of the phospholipid derivative subset (Cho, PC, PE, CDPC, PtC, GPC, GPE, and PUF) were observed, including a

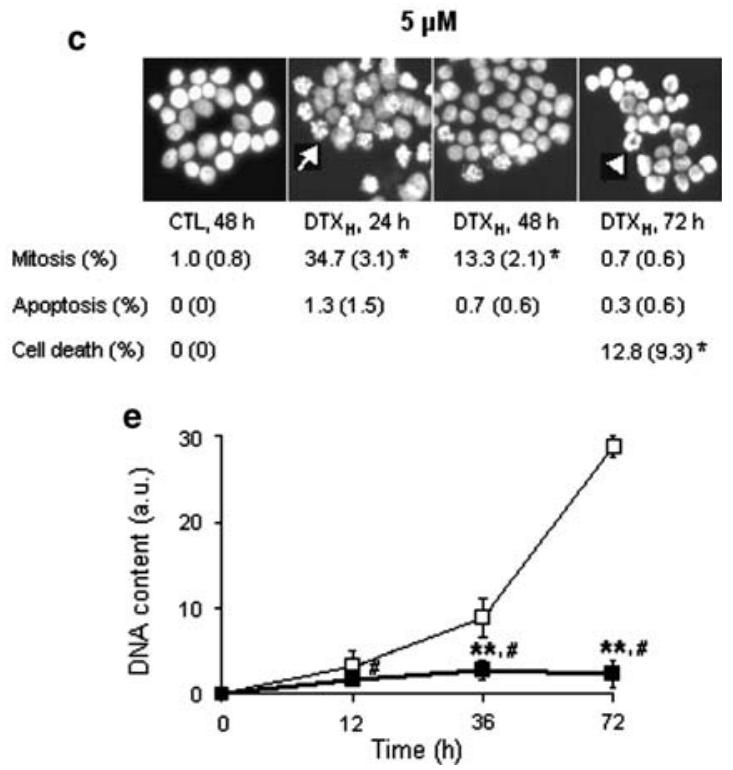

dose) for 24, 48, and $72 \mathrm{~h} \mathrm{(c).} \mathrm{Nuclear} \mathrm{morphology} \mathrm{was} \mathrm{assessed}$ under fluorescence microscopy (magnification $60 \times$ ), using Hoechst 33342 staining. Mitosis and apoptosis in DTX-treated cells were expressed as percentage of total attached cells. MCF7 cell death was evaluated from DNA content measurements at 36 and $72 \mathrm{~h}$. SD are in parenthesis. Full arrows indicate cells in mitotic arrest and arrow head, a tetraploid cell. $* P<0.05$ (treated vs. control, MannWhitney test). Variation in DNA content of attached MCF7 cells exposed to control (open squares) versus low dose of DTX (full squares) (d), and to control (open squares) versus high dose of DTX (full squares) (e) at 12, 36, and $72 \mathrm{~h}$. ** $P<0.01$ (treated vs. control, Mann-Whitney test); ${ }^{\#} P<0.05$ (low dose vs. high dose, MannWhitney test)

decrease in GPE by $-24 \%$ at $48 \mathrm{~h},-43 \%$ at $72 \mathrm{~h}$, and $-46 \%$ at $96 \mathrm{~h}$; PtC by $-70 \%$ at $72 \mathrm{~h}$; and GPC by $-51 \%$ at $72 \mathrm{~h}$ and $-58 \%$ at $96 \mathrm{~h}$ (all, $P<0.05$ ). Other metabolites increased, $\mathrm{PE}$ by $+79 \%$ at $48 \mathrm{~h},+125 \%$ at $72 \mathrm{~h}$, and $+114 \%$ at $96 \mathrm{~h} ; \mathrm{PC}$ by $+51 \%$ at $96 \mathrm{~h}$; CDPC by $+400 \%$ at $72 \mathrm{~h}$ and $+540 \%$ at $96 \mathrm{~h}$; and PUF by $+889 \%$ at $72 \mathrm{~h}$ and $+2048 \%$ at $96 \mathrm{~h}$ (all, $P<0.05$ ). In addition, there were variations in the glutathione metabolite subset (Met, $\mathrm{tCr}$, Ply, Hcy, hTa, Tau, GSx, Gln, Glu, and Arg), involving the increase in Tau by $+42 \%$ at $96 \mathrm{~h}(P<0.05)$ and the decrease in GSx by $-45 \%$ at $48 \mathrm{~h},-45 \%$ at $72 \mathrm{~h}$, and $-33 \%$ at $96 \mathrm{~h}$; Glu by $-89 \%$ at $72 \mathrm{~h}$, Arg by $-78 \%$ at $48 \mathrm{~h}$, and $-61 \%$ at $72 \mathrm{~h}$; and Hcy by $-75 \%$ at $96 \mathrm{~h}$ (all, $P<0.05$ ). Moreover, glycolysis was altered as shown by 
Fig. 2 Associated 1D and 2D ${ }^{1}$ H-HRMAS NMR spectra of MCF7 cells incubated without drug (a), with $5 \mu \mathrm{M}$ DTX (b), and $1 \mathrm{nM}$ DTX (c) for $72 \mathrm{~h}$ and of detached MCF7 cells having been exposed to $5 \mu \mathrm{M}$ DTX for 72 h (d). Boxes: GSx total glutathione; $P U F$ polyunsaturated fatty acids; $C D P C$ cytidinediphosphocholine; $W$ residual water signal (truncated)
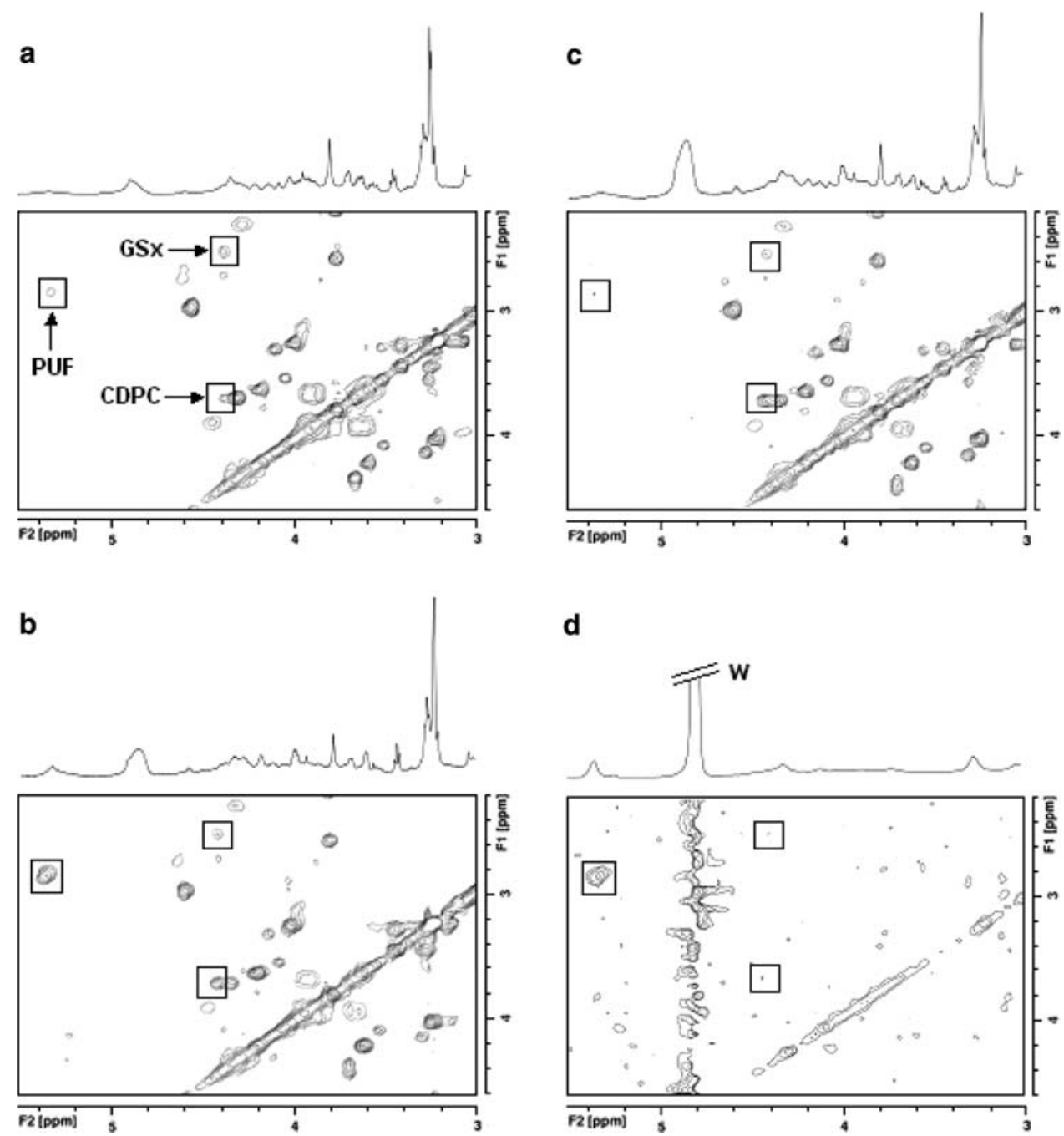

d

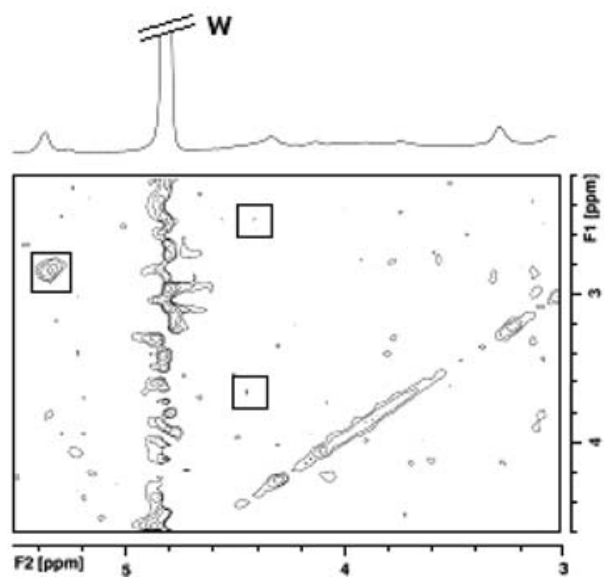

the decrease in Lac by $-56 \%$ at $72 \mathrm{~h}$ and $-51 \%$ at $96 \mathrm{~h}$; and Ace by $-92 \%$ at $72 \mathrm{~h}$ and $-94 \%$ at $96 \mathrm{~h}$ (all, $P<0.05)$.

To investigate relationships between metabolite and morphology changes, we compared GSx and phospholipid derivatives to DNA content and membrane integrity in the high dose DTX series (Fig. 4). Hcy and GSx varied in the same way, showing that Hcy primarily supported GSx biosynthesis, although Hcy varied in opposition to Tau at 72 h. Interestingly, GSx varied linearily with cellular DNA content (Fig. 4a), not with membrane integrity index (Fig. 4c). PtC and CDPC variations were opposite. PtC varied linearily with membrane integrity index (Fig. 4d), not with cellular DNA content (Fig. 4b).

Differential metabolomics of MCF7 cell response to docetaxel at high and low doses

Thirty metabolites were compared at high and low doses of DTX at $72 \mathrm{~h}$ (Fig. 5). At high dose, the subset of phospholipid derivatives showed the increase in $\mathrm{PE}$ by $+125 \%$, CDPC by $+400 \%$, and PUF by $+889 \%$ (all, $P<0.05)$, with the decrease in PtC by $-70 \%$, GPC by $-51 \%$, and GPE by $-43 \%$ (all, $P<0.05$ ). The subset of glutathione derivatives showed significant decrease in GSx $(-45 \%, P<0.05)$, Glu $(-89 \%, P<0.05)$, and Arg $(-61 \%$, $P<0.05$ ). Among the other metabolites (Asp, Asn, NAA, Pro, Ala, Gly, Thr, Phe, Lys, Lac, Ace, and MyI), there was a decrease in Lys $(-60 \%, P<0.05)$, Lac $(-54 \%, P<0.05)$, and Ace $(-92 \%, P<0.05)$ levels. At low dose, the subset of phospholipid derivatives showed the increase in $\mathrm{PE}$ by $+120 \%(P<0.05)$ and CDPC by $+586 \%(P<0.05)$ and the decrease in PtC by $-85 \%(P<0.05)$ and GPC by $-34 \%$ $(P<0.05)$. The subset of glutathione derivatives showed the increase in Hcy by $+144 \%(P<0.05)$ with the decrease in hTa by $-92 \%$, Tau by $-57 \%$, GSx by $-43 \%$, and Arg by $-68 \%$ (all, $P<0.05$ ). Among the other metabolites, significant alterations involved the increase in Asp by $+193 \%$ $(P<0.05)$ and the decrease in Ala by $-41 \%$, Thr by $-69 \%$, Lys by $-81 \%$, and Ace by $-92 \%$ (all, $P<0.05$ ). 
Fig. 3 Complete set of kinetics of variations (\% of control) for the 30 metabolites measured at $6,16,24,48,72$, and $96 \mathrm{~h}$ after DTX treatment at clinical dose $(5 \mu \mathrm{M})$. Abbreviations, as in text. $* P<0.05$ (MannWhitney test)
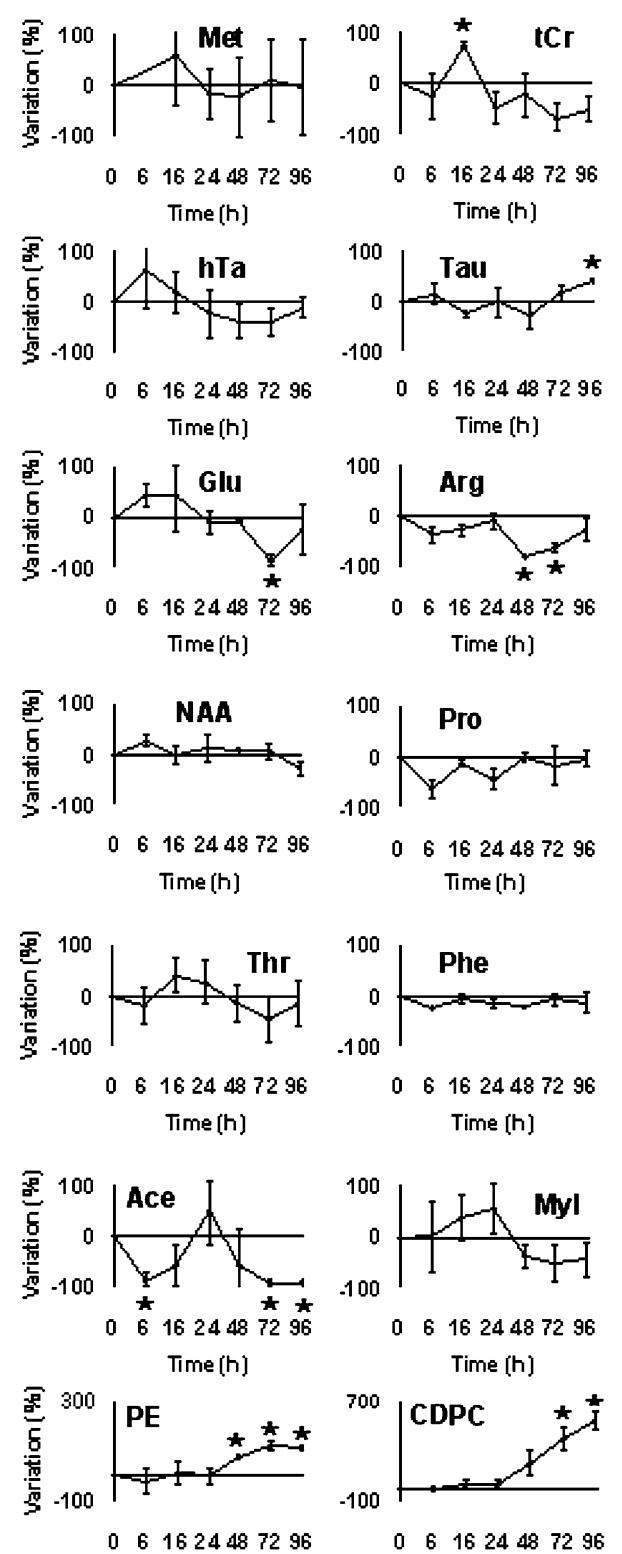

Time (h)

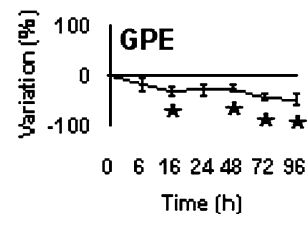

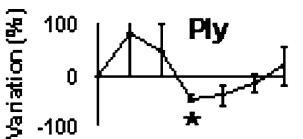

$\begin{array}{llll}0 & 6 & 162448 & 7296\end{array}$

Time [h]

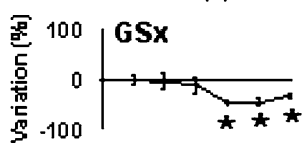

$\begin{array}{llll}0 & 6 & 16 & 24 \\ 48 & 7296\end{array}$

Time (h)

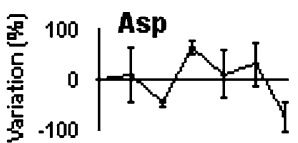

$\begin{array}{llllll}0 & 6 & 16 & 24 & 48 & 7296\end{array}$ Time (h)
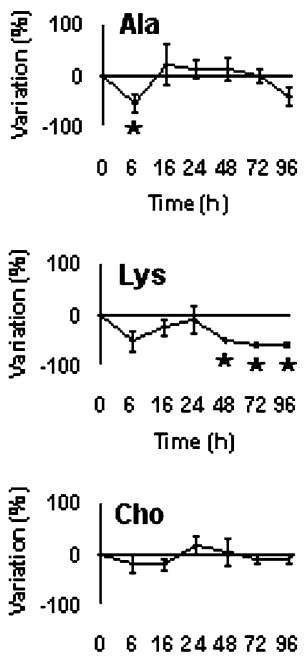

Time (h]

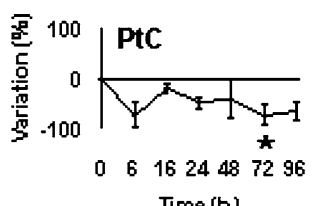

Time (h)

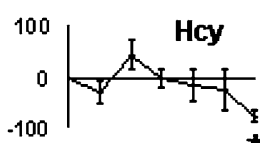

$\begin{array}{lllllll}0 & 6 & 16 & 24 & 48 & 7296\end{array}$

Time (h)

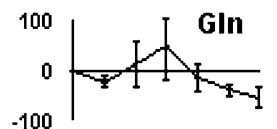

$\begin{array}{lllll}0 & 6 & 162448 & 7296\end{array}$

Time [h]

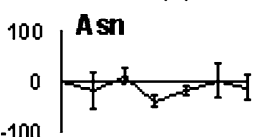

$\begin{array}{llllll}0 & 6 & 16 & 24 & 48 & 7296\end{array}$ Time (h)
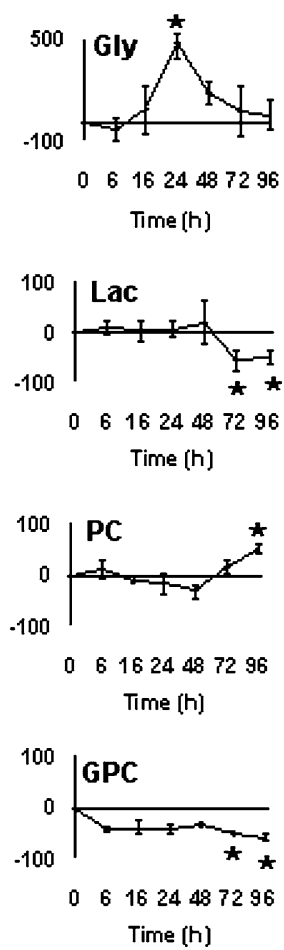

Table 1 shows metabolite content differences between high and low doses of DTX at $72 \mathrm{~h}$. The following derivatives varied significantly: Hcy, Tau, Gln, Glu, Asp, Ala, Lys, MyI, PC, GPC, GPE, and PUF (all, $P<0.05$ ). Among these metabolites, the largest variations were those of PUF (low dose-to-high dose variation of 14.8, $P<0.05$ ), Glu, MyI, and Hcy (high dose-to-low dose variation of 7.3, 3.8, and 3.1, respectively, $P<0.05$ ). Because PUF content was high in detached cells (Fig. 2d), we may consider PUF level as a biomarker of cytotoxicity. In addition to metabolite differential analysis, total GST activity of MCF7 cells was measured. GST activity was increased $(\times 5, P<0.01)$ at high dose and decreased $(-70 \%$, $P<0.01)$ at low dose of DTX.

Taken together, our pharmacometabolomics data enabled to propose an interpretation for MCF7 cell response to DTX at clinical and low doses, as reported in Fig. 6. 

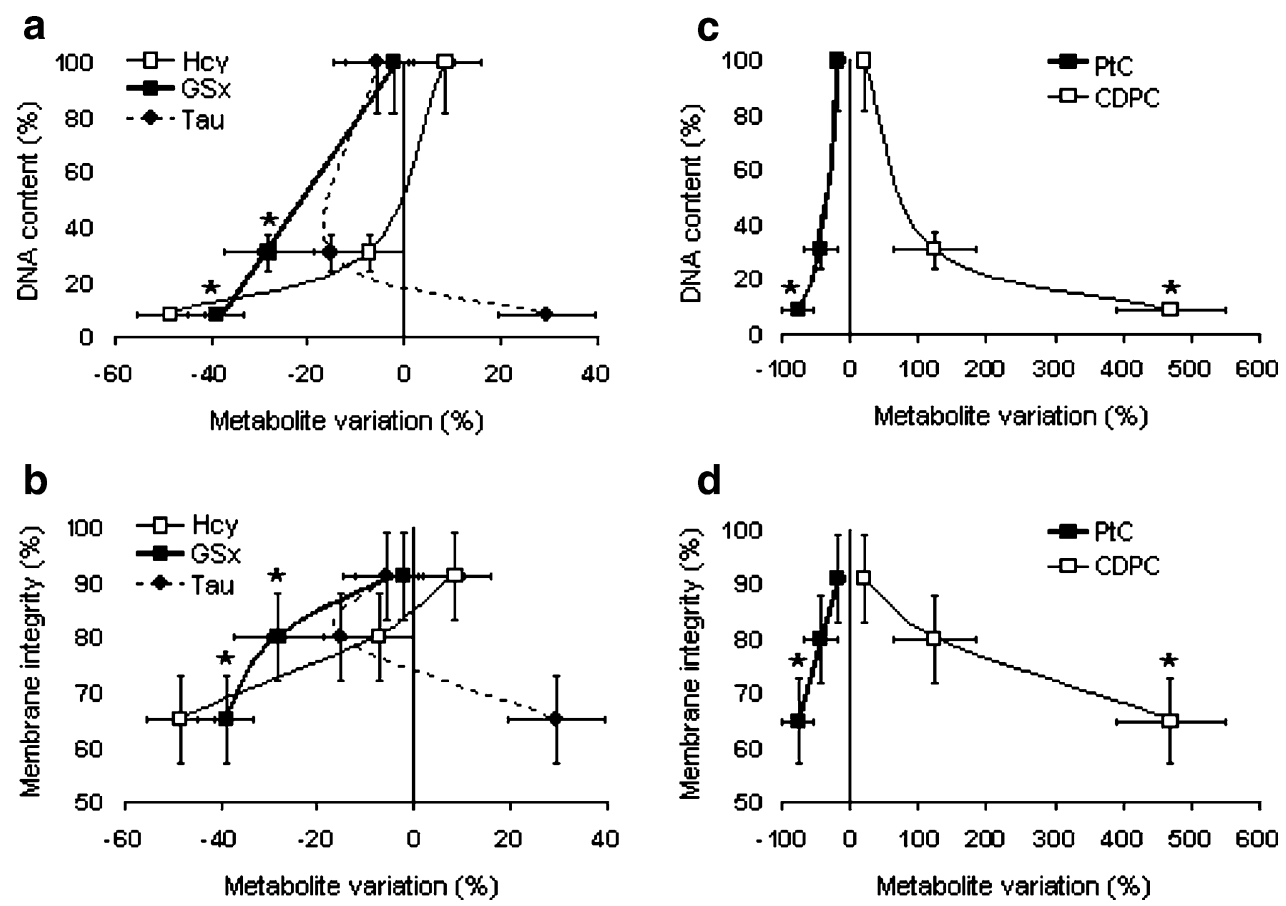

Fig. 4 Variation (\% of control) of glutathione metabolism derivatives, homocysteine (Hcy, open squares), total glutathione (GSx, full squares), and taurine (Tau, full losanges), as a function of DNA content (a) and membrane integrity index (b). Cellular DNA content (\% of control) was measured from Hoechst fluorescence intensity. Data points represent 12,36 , and $72 \mathrm{~h}$ exposure to $5 \mu \mathrm{M}$ DTX (clinical dose). GSx variation followed a linear relationship with DNA content according to: DNA content $(\%$ of control $)=104.69-$ $2.53 \times$ [unsigned GSx variation], $r^{2}=0.99(P<0.01)$. Variation $(\%$

of control) of phospholipid metabolism derivatives, phosphatidylcholine (PtC, full squares), and cytidinediphosphocholine (CDPC, open squares), as a function of DNA content (c) and membrane integrity index (d). Data points represent 12,36 , and $72 \mathrm{~h}$ exposure to $5 \mu \mathrm{M}$ DTX (clinical dose). PtC variation followed a linear relationship with membrane integrity according to: Membrane integrity index $(\%)=99.46-0.46 \times$ [unsigned $\mathrm{PtC}$ variation], $r^{2}=0.99(P<$ 0.01). Vertical and horizontal bars SD. $* P<0.05$ (treated vs. control cells, Mann-Whitney test)

\section{Discussion}

This study is, to our knowledge, the first pharmacometabolomics analysis of the response to DTX of MCF7 tumor cells. Metabolomics is increasingly considered as a valuable tool to describe cell phenotype. It is now applied to the field of pharmacology and takes part in the elucidation of drug response mechanisms. We here applied a recently developed NMR spectroscopy-based technique to profile the metabolite content of intact MCF7 breast cancer cells. The technique especially has the advantage of circumventing limitations of cell extraction procedures.

Varying cellular responses to DTX at high and low doses were observed in this study. The global response of MCF7 tumor cells involved a long-lasting cell cycle arrest in mitosis during the first $48 \mathrm{~h}$ of exposure to high dose of DTX, severe decrease in DNA content of attached cells together with reduction in DNA content at $72 \mathrm{~h}$, testifying cell death. No long-lasting cell cycle arrest in MCF7 cells exposed to low dose of DTX was observed, and DNA content was reduced but to a lesser extend than at high dose, without significant cell death in attached cells at $72 \mathrm{~h}$.

These findings are in agreement with literature reports. Low dose of DTX was shown to induce aberrant mitosis followed by aneuploidy and necrosis, whereas high dose induced mitotic arrest followed by mitotic slippage into tetraploid or "pseudo-G1" phase then apoptosis [10, 26]. Our DNA content measurements, reflecting cell proliferation and DNA ploidy although consistent with literature, underestimated antiproliferative effects of DTX at high dose because of cell tetraploidy. We did not observed significant apoptosis in MCF7 cells exposed to both doses of DTX. Actually, MCF7 cells are known to be partially resistant to apoptosis due to $\mathrm{Bcl}-2$ overexpression and caspase-3 defect [21].

We compared global response of MCF7 cells to DTX with metabolic response. Metabolite kinetics was obtained at clinical dose, and metabolite alteration as a function of dose was evaluated after $72 \mathrm{~h}$ exposure to treatment. At this time, after the exit from the normal cell cycle, cells both at low and high doses of DTX were engaged in a process of cell death or survival, thus enabling to observe mechanisms of DTX cytotoxicity and/or cell adaptation to treatment. Figure 6 summarizes our interpretation of 
Fig. 5 Variation (\% of control) of the 30 identified and quantified metabolites of MCF7 cells exposed to low ( $1 \mathrm{nM}$, light gray bars $)$ and high $(5 \mu \mathrm{M}$, dark bars) doses of DTX for

$72 \mathrm{~h}$. Measured metabolite abbreviations, as in text. * $P<0.05$ (treated vs. control cells, Mann-Whitney test). ${ }^{\#} P<0.05$ ( $1 \mathrm{nM}$ vs. $5 \mu \mathrm{M}$, Mann-Whitney test)

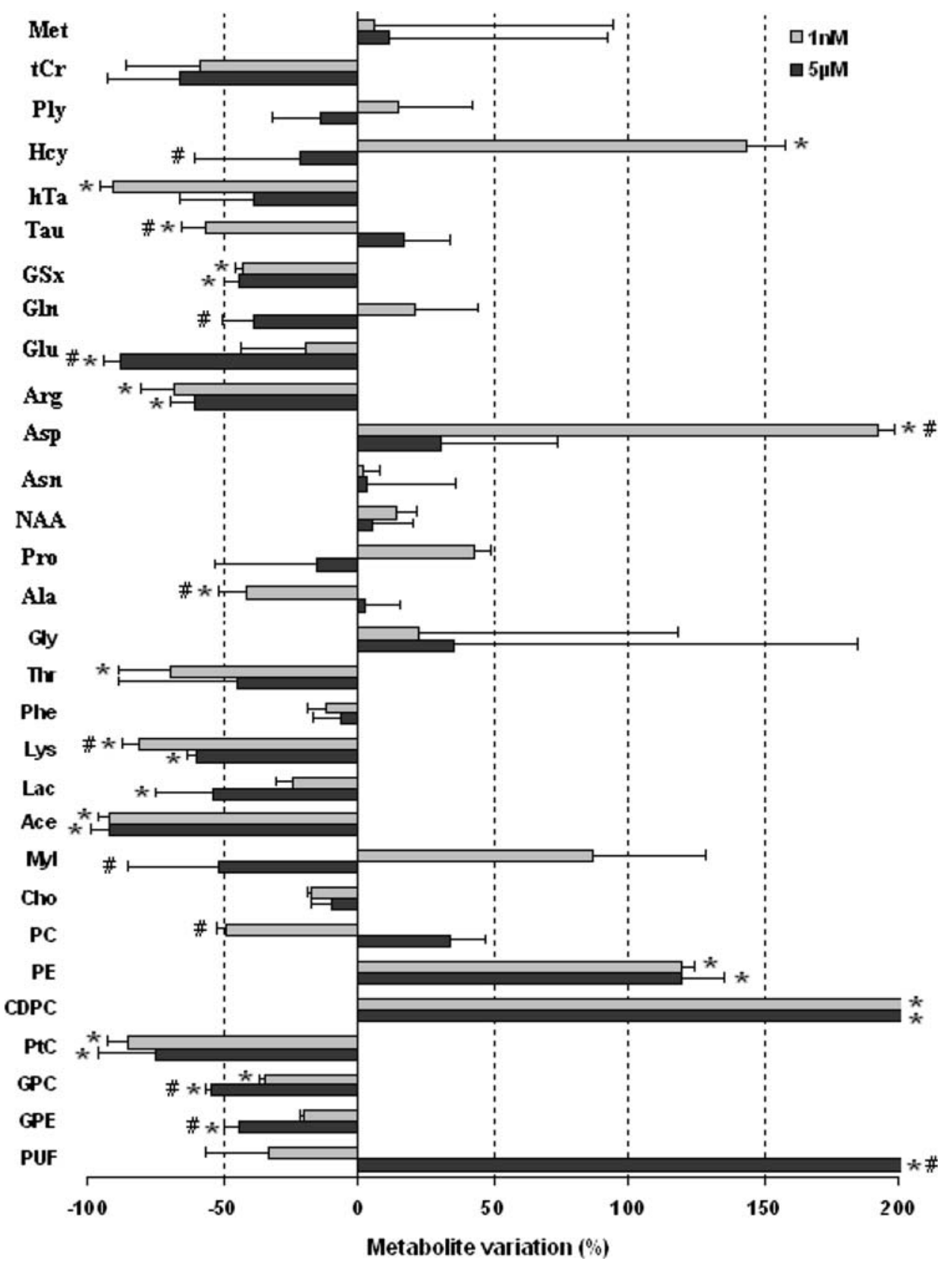

DTX-induced metabolic disorders and mechanistic data from the literature. Two major metabolic network subsets were interpreted, phospholipid metabolism and glutathione metabolism. At baseline, MCF7 cells displayed strong levels of GPC and GPE, which has been related to the hormonal status, to the metastatic potential, or to differences in membrane maintenance mechanisms [27]. At both high and low doses of DTX, the accumulation of CDPC together with the decrease in $\mathrm{PtC}$ provided evidence of a blockade of PtC biosynthesis at the choline phosphotransferase (CPT) level (Fig. 6a). The discriminant metabolic patterns between high and low doses of DTX involved PUF content and the mechanism for GSx decrease. At high dose, there was severe GSx consumption (increased GST activity), active transsulfuration explaining precursor starvation (decreased Hcy and Glu levels), whereas at low dose, there was a blockade of GSx synthesis at the first step of transsulfuration, as shown by Hcy accumulation (Fig. 6b). The possible origin of these findings is discussed below.

Among the most discriminating metabolic biomarkers of DTX dose-dependent effects, we found PUF, Glu, MyI, and Hcy. Glu and Hcy can be interpreted as members of the glutathione metabolism subset. PUF and MyI were more isolated metabolites in our profiling. At clinical dose, we 
Table 1 Variation of 30 metabolites in MCF7 cells in response to DTX

\begin{tabular}{|c|c|c|c|c|c|c|c|}
\hline \multirow[t]{2}{*}{ Metabolite } & \multicolumn{2}{|c|}{ High dose $(H, 5 \mu \mathrm{M})$} & \multicolumn{2}{|c|}{ Low dose $(\ell, 1 \mathrm{nM})$} & \multicolumn{3}{|l|}{ Between doses } \\
\hline & Fold change (SD) & $P$-value & Fold change (SD) & $P$-value & $H / \ell(\mathrm{SD})$ & $\ell / H(\mathrm{SD})$ & $P$-value \\
\hline Met & $1.11(1.82)$ & 0.8786 & $1.06(1.88)$ & 0.8786 & $1.05(2.80)$ & $0.95(2.23)$ & 1.0000 \\
\hline $\mathrm{tCr}$ & $0.32(0.73)$ & 0.1797 & $0.41(0.72)$ & 0.1797 & $0.78(1.50)$ & $1.28(1.38)$ & 0.6579 \\
\hline Ply & $0.86(0.82)$ & 0.8815 & $1.15(1.28)$ & 0.6547 & $0.75(2.53)$ & $1.34(2.68)$ & 0.2752 \\
\hline Hcy & $0.79(0.60)$ & 0.7642 & $2.44(1.15)$ & 0.0253 & $0.32(1.20)$ & $3.09(9.92)$ & 0.0495 \\
\hline hTa & $0.61(0.72)$ & 0.4561 & $0.08(0.96)$ & 0.0253 & $7.63(1.21)$ & $0.13(2.19)$ & 0.2752 \\
\hline Tau & $1.17(1.17)$ & 0.4561 & $0.43(0.91)$ & 0.0253 & $2.72(1.21)$ & $0.37(3.37)$ & 0.0495 \\
\hline GSx & $0.55(0.95)$ & 0.0253 & $0.57(0.97)$ & 0.0253 & $0.96(1.11)$ & $1.04(1.10)$ & 0.8273 \\
\hline Gln & $0.61(0.88)$ & 0.2967 & $1.21(1.23)$ & 0.6547 & $0.50(2.44)$ & $1.98(1.44)$ & 0.0495 \\
\hline Glu & $0.11(0.94)$ & 0.0339 & $0.80(0.76)$ & 0.6547 & $0.14(4.75)$ & $7.27(1.19)$ & 0.0495 \\
\hline Arg & $0.39(0.91)$ & 0.0339 & $0.32(0.87)$ & 0.0253 & $1.22(1.15)$ & $0.82(1.18)$ & 0.8273 \\
\hline Asp & $1.31(1.43)$ & 0.6547 & $2.93(1.06)$ & 0.0253 & 0.45 (1.16) & $2.24(7.20)$ & 0.0495 \\
\hline Asn & $1.03(1.33)$ & 0.8815 & $1.02(1.06)$ & 0.8815 & $1.01(6.45)$ & $0.99(5.30)$ & 0.8273 \\
\hline NAA & $1.05(1.16)$ & 0.8815 & 1.14 (1.07) & 0.2967 & $0.92(1.79)$ & $1.09(6.91)$ & 0.8273 \\
\hline Pro & $0.85(0.62)$ & 0.6547 & $1.43(1.06)$ & 0.1797 & $0.59(1.62)$ & $1.68(5.87)$ & 0.5127 \\
\hline Ala & $1.02(1.14)$ & 0.8815 & $0.59(0.89)$ & 0.0253 & $1.73(1.23)$ & $0.58(1.58)$ & 0.0495 \\
\hline Gly & $1.80(2.49)$ & 0.8815 & $1.23(1.96)$ & 0.6547 & $1.46(12.47)$ & 0.68 (1.91) & 0.6579 \\
\hline Thr & $0.55(0.56)$ & 0.4561 & $0.31(0.81)$ & 0.0339 & 1.77 (1.46) & $0.56(2.10)$ & 1.0000 \\
\hline Phe & $0.94(0.90)$ & 0.8815 & $0.88(0.93)$ & 0.8815 & 1.07 (1.63) & $0.94(3.17)$ & 0.8273 \\
\hline Lys & $0.40(0.97)$ & 0.0253 & $0.19(0.94)$ & 0.0253 & 2.11 & $0.48(1.09)$ & 0.0495 \\
\hline Lac & $0.46(0.79)$ & 0.0339 & $0.76(0.94)$ & 0.2967 & $0.61(1.74)$ & $1.65(1.14)$ & 0.1266 \\
\hline Ace & $0.08(0.93)$ & 0.0339 & $0.08(0.96)$ & 0.0339 & $1.00(1.06)$ & $1.00(1.06)$ & 1.0000 \\
\hline MyI & $0.49(0.66)$ & 0.3682 & $1.87(1.42)$ & 0.1797 & $0.26(1.34)$ & $3.82(1.99)$ & 0.0495 \\
\hline Cho & $0.89(0.92)$ & 0.4561 & $0.82(0.99)$ & 0.2967 & 1.09 (1.32) & $0.92(1.89)$ & 0.8273 \\
\hline $\mathrm{PC}$ & $1.17(1.13)$ & 0.4561 & $0.51(0.96)$ & 0.2967 & 2.29 (1.94) & $0.44(2.57)$ & 0.0495 \\
\hline PE & $2.25(1.16)$ & 0.0253 & $2.20(1.05)$ & 0.0253 & $1.02(1.01)$ & $0.98(1.89)$ & 0.8273 \\
\hline CDPC & $5.00(1.94)$ & 0.0253 & $6.86(1.36)$ & 0.0253 & $0.73(1.12)$ & $1.37(1.25)$ & 0.2752 \\
\hline $\mathrm{PtC}$ & $0.30(0.79)$ & 0.0339 & $0.15(0.92)$ & 0.0253 & $2.00(1.18)$ & $0.50(1.27)$ & 1.0000 \\
\hline GPC & $0.49(0.98)$ & 0.0253 & $0.66(0.98)$ & 0.0339 & $0.74(1.08)$ & $1.35(1.03)$ & 0.0495 \\
\hline GPE & $0.57(0.94)$ & 0.0253 & $0.80(0.98)$ & 0.1011 & $0.71(1.25)$ & $1.40(1.05)$ & 0.0495 \\
\hline PUF & $9.89(2.50)$ & 0.0253 & $0.67(0.77)$ & 0.8815 & $14.76(14.46)$ & $0.07(1.02)$ & 0.0495 \\
\hline
\end{tabular}

Fold change in metabolite content in MCF7 cells exposed to $5 \mu \mathrm{M}(H$ high dose $)$ and $1 \mathrm{nM}(\ell$ low dose $)$ of DTX for $72 \mathrm{~h}$ and between-dose comparison using the ratio of metabolite content at high dose to metabolite content at low dose $(H / \ell)$ and inversely $(\ell / H)$. Significant changes are in bold. Abbreviations, as in text; SD in parenthesis, fold change SD

found a dramatic accumulation of PUF starting from $48 \mathrm{~h}$ of treatment. PUF accumulation may result from hydrolysis of membranes [28], inhibition of PUF consumption, or inhibition of cyclooxygenase-2 (COX-2) activity [29]. Actually, taxanes have been shown to yield mobile lipid formation [28, 30] and variations of phospholipid metabolism derivatives [31], although not specifically among antineoplastic agents [28, 32-34]. PUF levels may relate an autophagic process implicating damaged membranes [30]. However, because in our study detached cells contained a large amount of PUF, PUF content may be a biomarker of DTX cytotoxicity at high dose. Another metabolite strongly varied between doses, MyI, which could be linked to the production of the bioactive lipid phosphatidylinositol (PtI).
Phospholipid metabolism was severely altered, and a common response was identified at high and low doses of DTX, consisting in the blockade of PtC biosynthesis at the last step of the Kennedy pathway, the CPT level (Fig. 6a). High and low doses of DTX induced the delayed accumulation of CDPC, associated with a rapid decrease in $\mathrm{PtC}$ and GPC as soon as $6 \mathrm{~h}$, suggesting that the disorder was initiated during the early response to DTX. However, the delayed CDPC variation suggests an adaptive period preceeding the collapse of the CDPC pathway. This collapse may be a cytotoxicity mechanism [35]. DAG is the other substrate for CPT. Because CPT is not the regulatory enzyme of the Kennedy pathway, the observed blockade should result from insufficient DAG availability. First, there 


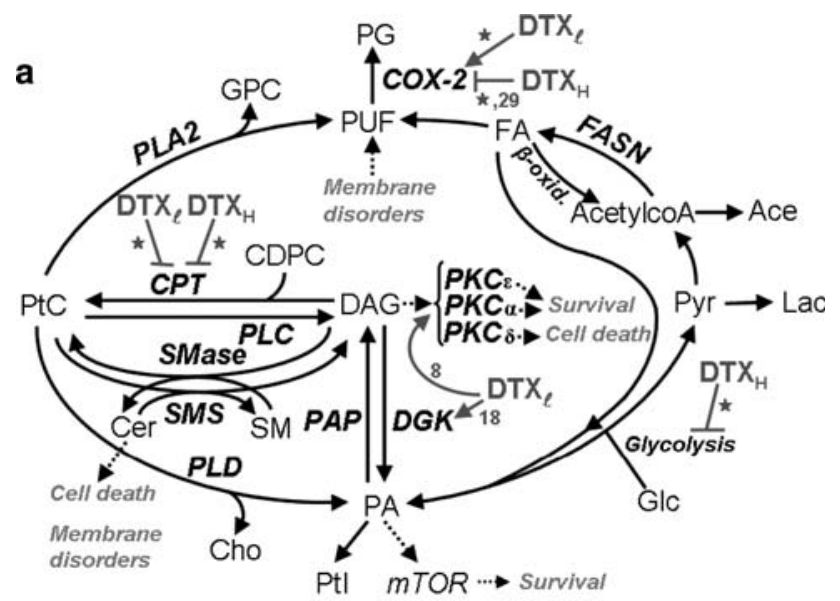

b

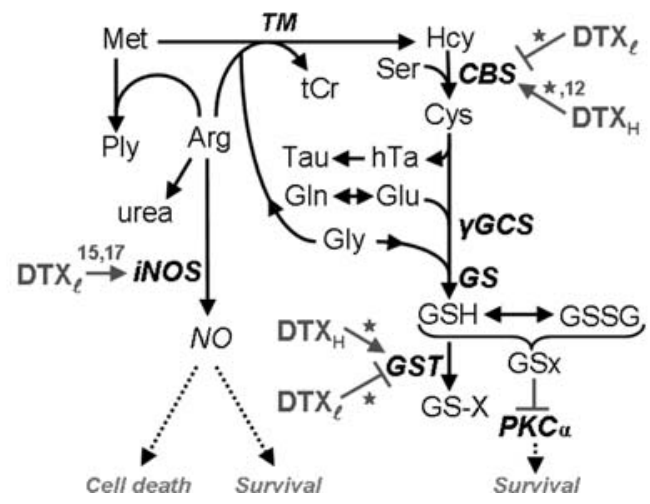

Fig. 6 Biochemical findings and interpretation of the response to DTX for the phospholipid metabolism subset (a) and the glutathione metabolism subset (b). Subscript $H$, high dose $(5 \mu \mathrm{M})$ DTX; subscript $\ell$, low dose ( $1 \mathrm{nM})$ DTX; filled asterisk, our findings; number, literature reference; $\leftarrow$, activation; $\vdash$, inhibition. a Abbreviations for measured metabolites, as in text; $C e r$, ceramide; $D A G$, diacylglycerol; $F A$, fatty acid; Glc, glucose; $P A$, phosphatidic acid; $P t I$, phosphatidylinositol; $P G$, prostaglandin; $P y r$, pyruvate; $S M$, sphingomyelin. $C P T$, choline phosphotransferase; $C O X-2$, cyclooxygenase-2; $D G K$, diacylglycerol kinase; $F A S N$, fatty acid synthase; $\beta$-oxid, betaoxidation; $P A P$, phosphatidic acid phosphatase; $P L C$, phospholipase $\mathrm{C} ; P L D$, phospholipase $\mathrm{D} ; P K C \delta$, protein kinase C-delta; $P K C \varepsilon$, protein kinase C-epsilon; SMase, sphingomyelinase; SMS, sphingomyelin synthase; $m T O R$, mammalian target of rapamycin. b Abbreviations for measured metabolites, as in text; $C y s$, cysteine; NO, nitric oxide; $G S-X$, glutathione conjugate. $C B S$, cystathionine beta-synthase; $\gamma G C S$, gamma-glutamylcysteine synthetase; GST, glutathione $S$-transferase; iNOS, inducible nitric oxide synthase; $P K C \alpha$, protein kinase C-alpha; $T M$, transmethylation

may be an effective decrease in DAG as a consequence of the downregulation of glycolysis [35]. Our metabolic data support glycolysis disorders with the significant decrease in Lac and Ace. Actually, glycolysis supplies glycerophosphate, the precursor of PA. Indeed, it was previously shown by ${ }^{31} \mathrm{P}-\mathrm{NMR}$ spectroscopy that induction of apoptosis by farnesol resulted in increased level of CDPC in favor of CPT blockade and the accumulation of fructose-1,6-bisphosphate, a glycolysis derivative, in favor of glycolysis downregulation. Second, DAG decrease could result from decreased hydrolysis of phospholipids, such as $\mathrm{PtC}$ via the inhibition of phospholipase C or D activity, as shown for farnesol cytotoxicity [36, 37]. Third, CPT blockade may also be due to a rerouting of DAG through the activation of protein kinase C (PKC) or diacylglycerol kinase (DGK). PKCs are a family of 'conventional' PKCs $(\alpha, \beta 1, \beta 2$, and $\gamma)$ activated by DAG binding, 'novel' PKCs $(\delta, \varepsilon, \eta, \mu$, and $\theta)$, which are DAG-dependent, and 'atypical' PKCs $(l, \lambda$, and $\zeta)$ also DAG-independent [38]. It was recently shown that DTX activated $\mathrm{PKC} \varepsilon$ and $\mathrm{PKC} \delta$ in melanoma cells [8]. The activation of $\mathrm{PKC} \varepsilon$ was increased in human DTX-resistant cells and associated with prosurvival signaling through ERK1/2 pathway activation. In contrast to $\mathrm{PKC} \varepsilon$, high levels of activated $\operatorname{PKC} \delta$ were associated with sensitivity to DTX and proapoptotic response through JNK activation [38]. PKC $\delta$-mediated cell death could result from allosteric activation of this PKC isoform or activation of p38 MAPK, as shown in prostate LNCaP cells [39, 40]. Also DAG can be consumed into $\mathrm{PtC}$ and produce ceramide, a proapoptotic lipid, by the activity of sphingomyelinase. DAG can be phosphorylated by DGK to produce PA, a precursor of signaling phospholipids such as PtI and an activator of mTOR signaling, involved in cell survival and autophagy [41]. mTOR may be downregulated through a reduction in PA level [42]. DTX at low concentration $(10 \mathrm{nM})$ was shown to activate DGK, a lipid kinase that catalyzes DAG conversion into PA. DTX triggers a metabolic cascade consisting in phospholipase D-mediated PtC hydrolysis, PA release, phosphatidic acid phosphatase-dependent DAG production, and DGK stimulation leading to DAG conversion back to PA [18]. Finally, another mechanism for CPT blockade may be proposed, a competition between DAG and cholesterol precursors, a mechanism which was shown to provoke CDPC accumulation and inhibit PtC biosynthesis [43]. At clinical dose of DTX, PtC was found to be a positive biomarker of membrane integrity. Actually, ceramide production following upregulation of sphingomyelinase is associated with increased cell membrane permeability [44]. Insufficient PtC biosynthesis, like we observed, could, in turn, explain decreased membrane biosynthesis and repair.

The other major metabolic pathway to be altered was glutathione metabolism, in a dose-dependent manner (Fig. 6b). At high dose of DTX, the simultaneous decrease in Hcy and Glu, as well as the increase in GST activity, indicated dramatic GSx consumption, accompanied by active transsulfuration. The increase in GST activity testified involvement of detoxification processes as a cellular adaptive response to counteract DTX cytotoxicity at high concentration. At low dose, decreased GSx level resulted from the blockade of GSx biosynthesis at an early step of transsulfuration as testified by Hcy accumulation, probably 
at the level of cystathionine beta-synthase (CBS), the major regulatory enzyme of transsulfuration [45]. Here also the time-dependent response of MCF7 cells to DTX suggested an adaptive period followed by the collapse of transsulfuration and the decrease in GSx levels, a classical cytotoxicity mechanism. The same disorder explained decreased biosynthesis of downstream products of transsulfuration (GSx, hTa, and Tau). CBS activity depends on the cellular redox state and is inhibited by NO or acidosis [46] and activated by ROS [45]. The balance between NO and ROS levels was shown as an important mechanism of the response to paclitaxel at low concentration $[13,46]$. In this study, at low dose of DTX, we found blockade of CBS as well as acidosis. These findings are in agreement with literature data on the implication of NO in the response of cancer cells to low dose of DTX [12, 15]. In contrast, at high dose of DTX, NO effect on CBS enzyme should be conterbalanced and overwhelmed by accumulating ROS effects. Another rate-limiting enzyme of GSH biosynthesis, gamma-glutamylcysteine synthetase, downstream CBS, is known to be transcriptionally upregulated by ROS [47] and may participate to the starvation of the GSH biosynthetic pathway. Furthermore, NO originates from iNOS, which catabolizes Arg to form NO and citrulline. The decrease in Arg that we found at low dose of DTX may reflect NO production and at high dose, may be a consequence of Glu excessive consumption. Actually, DTX was shown to enhance iNOS expression [15] and NO production [16] in breast cancer cells and through stimulation of p38 activity in alveolar macrophages [17]. NO also mediates sphingomyelinase activation and apoptotic process through ceramide production [48]. Moreover, GSx depletion is associated with lipid peroxidation and oxidative DNA damage [49]. It was found to be associated with lipid accumulation in human erythroleukemia K562 cells exposed to paclitaxel $[28,32]$ and to PE accumulation in B16 melanoma cells exposed to oxidative stress [50]. Conversely, GSx depletion may activate $\mathrm{PKC} \alpha$ [51], as a survival process.

In conclusion, this pharmacometabolomics study provides new insight into the mechanism of the varying cellular response to DTX at clinical (high) and low doses. Major variations implicated glycolysis, phospholipid metabolism, and glutathione metabolism. Among the most discriminant metabolites between high and low doses were PUF, Glu, MyI, and Hcy. Although a common response to both doses was PtC biosynthesis blockade, differential responses between doses involved PUF accumulation and the mechanism for GSx decrease, excessive consumption at high dose, and biosynthesis blockade at low dose. In addition, this study offers a basis for translational studies of metabolites varying in response to DTX into clinical endpoints.
Acknowledgments The authors thank Dr Anne Cayre for microscopy analysis. This work was supported by La Ligue Régionale Contre le Cancer (Comités du Cantal et du Puy de Dôme).

\section{References}

1. Parkin DM (2004) International variation. Oncogene 23:6329_ 6340. doi: $10.1038 /$ sj.onc. 1207726

2. Lacey JV Jr, Devesa SS, Brinton LA (2002) Recent trends in breast cancer incidence and mortality. Environ Mol Mutagen 39: 82-88. doi:10.1002/em.10062

3. Chan S, Friedrichs K, Noel D, Pinter T, Van Belle S, Vorobiof D, Duarte R, Gil Gil M, Bodrogi I, Murray E, Yelle L, Von Minckwitz G, Korec S, Simmonds P, Buzzi F, Gonzalez Mancha R, Richardson G, Walpole E, Ronzoni M, Murawsky M, Alakl M, Riva A, Crown J (1999) Prospective randomized trial of docetaxel versus doxorubicin in patients with metastatic breast cancer. J Clin Oncol 17:2341-2354

4. Nabholtz JM, Senn HJ, Bezwoda WR, Melnychuk D, Deschenes L, Douma J, Vandenberg TA, Rapoport B, Rosso R, Trillet-Lenoir V, Drbal J, Molino A, Nortier JW, Richel DJ, Nagykalnai T, Siedlecki P, Wilking N, Genot JY, Hupperets PS, Pannuti F, Skarlos D, Tomiak EM, Murawsky M, Alakl M, Aapro M et al (1999) Prospective randomized trial of docetaxel versus mitomycin plus vinblastine in patients with metastatic breast cancer progressing despite previous anthracycline-containing chemotherapy. 304 Study Group. J Clin Oncol 17:1413-1424

5. Ford HE, Yap YS, Miles DW, Makris A, Hall M, Miller L, Harries M, Smith IE, Johnston SR (2006) A phase II study of weekly docetaxel in patients with anthracycline pretreated metastatic breast cancer. Cancer Chemother Pharmacol 58:809-815. doi:10.1007/s00280-006-0222-9

6. Ringel I, Horwitz SB (1991) Studies with RP 56976 (taxotere): a semisynthetic analogue of taxol. J Natl Cancer Inst 83:288-291. doi:10.1093/jnci/83.4.288

7. Sweeney CJ, Miller KD, Sissons SE, Nozaki S, Heilman DK, Shen J, Sledge GW Jr (2001) The antiangiogenic property of docetaxel is synergistic with a recombinant humanized monoclonal antibody against vascular endothelial growth factor or 2methoxyestradiol but antagonized by endothelial growth factors. Cancer Res 61:3369-3372

8. Mhaidat NM, Thorne RF, Zhang XD, Hersey P (2007) Regulation of docetaxel-induced apoptosis of human melanoma cells by different isoforms of protein kinase C. Mol Cancer Res 5:10731081. doi:10.1158/1541-7786.MCR-07-0059

9. Wang LG, Liu XM, Kreis W, Budman DR (1999) The effect of antimicrotubule agents on signal transduction pathways of apoptosis: a review. Cancer Chemother Pharmacol 44:355-361. doi: $10.1007 / \mathrm{s} 002800050989$

10. Hernandez-Vargas H, Palacios J, Moreno-Bueno G (2007) Molecular profiling of docetaxel cytotoxicity in breast cancer cells: uncoupling of aberrant mitosis and apoptosis. Oncogene 26: 2902-2913. doi:10.1038/sj.onc.1210102

11. Noguchi S (2006) Predictive factors for response to docetaxel in human breast cancers. Cancer Sci 97:813-820. doi:10.1111/j.13497006.2006.00265.x

12. Mizumachi T, Suzuki S, Naito A, Carcel-Trullols J, Evans TT, Spring PM, Oridate N, Furuta Y, Fukuda S, Higuchi M (2008) Increased mitochondrial DNA induces acquired docetaxel resistance in head and neck cancer cells. Oncogene 27:831-838. doi: 10.1038/sj.onc. 1210681

13. Ramanathan B, Jan KY, Chen $\mathrm{CH}$, Hour TC, Yu HJ, Pu YS (2005) Resistance to paclitaxel is proportional to cellular total antioxidant capacity. Cancer Res 65:8455-8460. doi:10.1158/ 0008-5472.CAN-05-1162 
14. Alexandre J, Hu Y, Lu W, Pelicano H, Huang P (2007) Novel action of paclitaxel against cancer cells: bystander effect mediated by reactive oxygen species. Cancer Res 67:3512-3517. doi: 10.1158/0008-5472.CAN-06-3914

15. Oktem G, Karabulut B, Selvi N, Sezgin C, Sanli UA, Uslu R, Yurtseven ME, Omay SB (2004) Differential effects of doxorubicin and docetaxel on nitric oxide production and inducible nitric oxide synthase expression in MCF-7 human breast cancer cells. Oncol Res 14:381-386

16. Oktem G, Bilir A, Selvi N, Yurtseven ME, Vatansever S, Ates U, Uysal A, Omay SB (2006) Chemotherapy influences inducible nitric oxide synthase (iNOS) and endothelial nitric oxide synthase (eNOS) activity on 3D breast cancer cell line. Oncol Res 16:195-203

17. Saito F, Matsusaka S, Takahashi Y, Wakabayashi I (2008) Enhancement of nitric oxide synthase induction in alveolar macrophages by in vivo administration of docetaxel. Eur J Pharmacol 580:425-430. doi:10.1016/j.ejphar.2007.11.006

18. Maestre N, Bezombes C, Plo I, Levade T, Lavelle F, Laurent G, Jaffrezou JP (2003) Phosphatidylcholine-derived phosphatidic acid and diacylglycerol are involved in the signaling pathways activated by docetaxel. J Exp Ther Oncol 3:36-46. doi:10.1046/ j.1359-4117.2003.01065.x

19. Torres K, Horwitz SB (1998) Mechanisms of Taxol-induced cell death are concentration dependent. Cancer Res 58:3620-3626

20. Hernandez-Vargas H, Palacios J, Moreno-Bueno G (2007) Telling cells how to die: docetaxel therapy in cancer cell lines. Cell Cycle 6:780-783

21. Morse DL, Gray H, Payne CM, Gillies RJ (2005) Docetaxel induces cell death through mitotic catastrophe in human breast cancer cells. Mol Cancer Ther 4:1495-1504. doi:10.1158/15357163.MCT-05-0130

22. Morvan D, Demidem A (2007) Metabolomics by proton nuclear magnetic resonance spectroscopy of the response to chloroethylnitrosourea reveals drug efficacy and tumor adaptive metabolic pathways. Cancer Res 67:2150-2159. doi:10.1158/0008-5472. CAN-06-2346

23. Rago R, Mitchen J, Wilding G (1990) DNA fluorometric assay in 96-well tissue culture plates using Hoechst 33258 after cell lysis by freezing in distilled water. Anal Biochem 191:31-34. doi: 10.1016/0003-2697(90)90382-J

24. Habig WH, Pabst MJ, Jakoby WB (1974) Glutathione S-transferases. The first enzymatic step in mercapturic acid formation. $\mathrm{J}$ Biol Chem 249:7130-7139

25. Morvan D, Demidem A, Guenin S, Madelmont JC (2006) Methionine-dependence phenotype of tumors: metabolite profiling in a melanoma model using L-[methyl-13C] methionine and high-resolution magic angle spinning $1 \mathrm{H}-13 \mathrm{C}$ nuclear magnetic resonance spectroscopy. Magn Reson Med 55:984-996. doi: 10.1002/mrm. 20869

26. Blajeski AL, Kottke TJ, Kaufmann SH (2001) A multistep model for paclitaxel-induced apoptosis in human breast cancer cell lines. Exp Cell Res 270:277-288. doi:10.1006/excr.2001.5349

27. Sterin M, Cohen JS, Mardor Y, Berman E, Ringel I (2001) Levels of phospholipid metabolites in breast cancer cells treated with antimitotic drugs: a 31P-magnetic resonance spectroscopy study. Cancer Res 61:7536-7543

28. Brisdelli F, Iorio E, Knijn A, Ferretti A, Marcheggiani D, Lenti L, Strom R, Podo F, Bozzi A (2003) Two-step formation of $1 \mathrm{H}$ NMR visible mobile lipids during apoptosis of paclitaxel-treated K562 cells. Biochem Pharmacol 65:1271-1280. doi:10.1016/ S0006-2952(03)00080-7

29. Subbaramaiah K, Marmo TP, Dixon DA, Dannenberg AJ (2003) Regulation of cyclooxgenase-2 mRNA stability by taxanes: evidence for involvement of p38, MAPKAPK-2, and HuR. J Biol Chem 278:37637-37647. doi:10.1074/jbc.M301481200
30. Reggiori F, Klionsky DJ (2005) Autophagosomes: biogenesis from scratch? Curr Opin Cell Biol 17:415-422. doi:10.1016/ j.ceb.2005.06.007

31. Morse DL, Raghunand N, Sadarangani P, Murthi S, Job C, Day S, Howison C, Gillies RJ (2007) Response of choline metabolites to docetaxel therapy is quantified in vivo by localized (31)P MRS of human breast cancer xenografts and in vitro by high-resolution (31)P NMR spectroscopy of cell extracts. Magn Reson Med 58:270-280. doi:10.1002/mrm.21333

32. Knijn A, Brisdelli F, Ferretti A, Iorio E, Marcheggiani D, Bozzi A (2005) Metabolic alterations in K562 cells exposed to taxol and tyrphostin AG957: 1H NMR and biochemical studies. Cell Biol Int 29:890-897. doi:10.1016/j.cellbi.2005.07.004

33. Morvan D, Demidem A, Papon J, De Latour M, Madelmont JC (2002) Melanoma tumors acquire a new phospholipid metabolism phenotype under cystemustine as revealed by high-resolution magic angle spinning proton nuclear magnetic resonance spectroscopy of intact tumor samples. Cancer Res 62:1890-1897

34. Morvan D, Demidem A, Papon J, Madelmont JC (2003) Quantitative HRMAS proton total correlation spectroscopy applied to cultured melanoma cells treated by chloroethyl nitrosourea: demonstration of phospholipid metabolism alterations. Magn Reson Med 49:241-248. doi:10.1002/mrm.10368

35. Williams SN, Anthony ML, Brindle KM (1998) Induction of apoptosis in two mammalian cell lines results in increased levels of fructose-1, 6-bisphosphate and CDP-choline as determined by 31P MRS. Magn Reson Med 40:411-420. doi:10.1002/mrm. 1910400311

36. Taylor MM, Macdonald K, Morris AJ, McMaster CR (2005) Enhanced apoptosis through farnesol inhibition of phospholipase D signal transduction. FEBS J 272:5056-5063. doi:10.1111/ j.1742-4658.2005.04914.x

37. Voziyan PA, Haug JS, Melnykovych G (1995) Mechanism of farnesol cytotoxicity: further evidence for the role of PKCdependent signal transduction in farnesol-induced apoptotic cell death. Biochem Biophys Res Commun 212:479-486. doi:10.1006/ bbrc.1995.1995

38. Griner EM, Kazanietz MG (2007) Protein kinase C and other diacylglycerol effectors in cancer. Nat Rev Cancer 7:281-294. doi: $10.1038 / \mathrm{nrc} 2110$

39. Fujii T, Garcia-Bermejo ML, Bernabo JL, Caamano J, Ohba M, Kuroki T, Li L, Yuspa SH, Kazanietz MG (2000) Involvement of protein kinase $\mathrm{C}$ delta (PKCdelta) in phorbol ester-induced apoptosis in $\mathrm{LNCaP}$ prostate cancer cells. Lack of proteolytic cleavage of PKCdelta. J Biol Chem 275:7574-7582. doi:10.1074/ jbc.275.11.7574

40. Tanaka Y, Gavrielides MV, Mitsuuchi Y, Fujii T, Kazanietz MG (2003) Protein kinase C promotes apoptosis in LNCaP prostate cancer cells through activation of p38 MAPK and inhibition of the Akt survival pathway. J Biol Chem 278:33753-33762. doi: 10.1074/jbc.M303313200

41. Pattingre S, Espert L, Biard-Piechaczyk M, Codogno P (2008) Regulation of macroautophagy by mTOR and Beclin $1 \mathrm{com}-$ plexes. Biochimie 90:313-323. doi:10.1016/j.biochi.2007.08.014

42. Merida I, Avila-Flores A, Merino E (2008) Diacylglycerol kinases: at the hub of cell signalling. Biochem J 409:1-18. doi:10.1042/ BJ20071040

43. Wright MM, Henneberry AL, Lagace TA, Ridgway ND, McMaster CR (2001) Uncoupling farnesol-induced apoptosis from its inhibition of phosphatidylcholine synthesis. J Biol Chem 276: 25254 25261. doi:10.1074/jbc.M011552200

44. Ruiz-Arguello MB, Basanez G, Goni FM, Alonso A (1996) Different effects of enzyme-generated ceramides and diacylglycerols in phospholipid membrane fusion and leakage. J Biol Chem 271: 26616-26621. doi:10.1074/jbc.271.43.26616 
45. Mosharov E, Cranford MR, Banerjee R (2000) The quantitatively important relationship between homocysteine metabolism and glutathione synthesis by the transsulfuration pathway and its regulation by redox changes. Biochemistry 39:13005-13011. doi: 10.1021/bi001088w

46. Prathapasinghe GA, Siow YL, Xu Z, O K (2008) Inhibition of cystathionine-beta-synthase activity during renal ischemiareperfusion: role of $\mathrm{pH}$ and nitric oxide. Am J Physiol Renal Physiol 295:F912-F922. doi:10.1152/ajprenal.00040.2008

47. Iwata-Ichikawa E, Kondo Y, Miyazaki I, Asanuma M, Ogawa N (1999) Glial cells protect neurons against oxidative stress via transcriptional up-regulation of the glutathione synthesis. J Neurochem 72:2334-2344. doi:10.1046/j.1471-4159.1999.0722334.x

48. Perrotta C, De Palma C, Falcone S, Sciorati C, Clementi E (2005) Nitric oxide, ceramide and sphingomyelinase-coupled receptors: a tale of enzymes and messengers coordinating cell death, survival and differentiation. Life Sci 77:1732-1739. doi:10.1016/ j.lfs.2005.05.016

49. Beddowes EJ, Faux SP, Chipman JK (2003) Chloroform, carbon tetrachloride and glutathione depletion induce secondary genotoxicity in liver cells via oxidative stress. Toxicology 187:101115. doi:10.1016/S0300-483X(03)00058-1

50. Demidem A, Morvan D, Madelmont JC (2006) Bystander effects are induced by CENU treatment and associated with altered protein secretory activity of treated tumor cells: a relay for chemotherapy? Int J Cancer 119:992-1004. doi:10.1002/ijc.21761

51. Ward NE, Pierce DS, Chung SE, Gravitt KR, O'Brian CA (1998) Irreversible inactivation of protein kinase $\mathrm{C}$ by glutathione. $\mathrm{J}$ Biol Chem 273:12558-12566. doi:10.1074/jbc.273.20.12558 